\title{
Investigation into the Thermal Annealing Effect on the Photovoltaic Properties of Organic Solar Cells based on $\mathrm{CuPc} / \mathrm{C}_{60}$ Heterojunctions
}

\author{
Seunguk NoH, Seohee Kim, Jungjin YANG and Changhee LeE* \\ School of Electrical Engineering and Computer Science, \\ Inter-university Semiconductor Research Center, Seoul National University, Seoul 151-742 \\ Ji-Young KIM \\ Interdisciplinary Graduate Program in Nanoscience and Nanotechnology, Seoul National University, Seoul 151-742
}

(Received 12 December 2007)

\begin{abstract}
We studied the effect of post-annealing treatment on the photovoltaic (PV) properties of organic solar cells based on copper phthalocyanine $(\mathrm{CuPc}) /$ fullerene $\left(\mathrm{C}_{60}\right)$ heterojunctions. In the device structure of ITO/CuPc $(30 \mathrm{~nm}) / \mathrm{C}_{60}(40 \mathrm{~nm}) / \mathrm{BCP}(10 \mathrm{~nm}) / \mathrm{LiF}(0.5 \mathrm{~nm}) / \mathrm{Al}$, where BCP is 2,9-dimethyl-4,7-diphenyl-phenanthroline acting as an exciton blocking layer, a maximum power conversion efficiency $\left(\eta_{p}\right)$ of about $1 \%$ under an AM 1.5 solar illumination intensity of $100 \mathrm{~mW} / \mathrm{cm}^{2}$ was obtained at room temperature. By measuring the PV characteristics for the devices annealed at various temperatures for 30 minutes, we found that the short-circuit current and efficiency increased with increasing annealing temperature up to $100{ }^{\circ} \mathrm{C}\left(\eta_{p} \sim 1.3 \%\right)$ and then decreased at higher temperatures. We analyzed the effect of thermal annealing on the improved device performance by measuring the optical absorption spectra and the X-ray diffraction patterns of the $\mathrm{CuPc} / \mathrm{C}_{60}$ films.
\end{abstract}

PACS numbers: 84.60.Jt, 73.50.Pz, 72.80.Le, 73.61.Ph, 81.40.Gh

Keywords: Organic solar cells, $\mathrm{CuPc}, \mathrm{C}_{60}, \mathrm{BCP}$, Thermal annealing

\section{INTRODUCTION}

Solar cells have been attractive because they can replace polluting and depleting fossil fuels with clean, infinite and renewable solar energy. Especially, organic solar cells have many benefits due to ease of fabrication, lowcost production of large-area devices and compatibility with flexible substrates compared to inorganic solar cells [1-4]. However, there are many technical issues, such as poor stability and low efficiency, concerning for their practical applications $[5,6]$.

Although organic materials have higher absorption coefficients than inorganic materials, low carrier generation efficiency, short exciton diffusion length and low carrier mobility are disadvantages [5]. The carrier generation efficiency can be enhanced by using the bilayer structure with an electron donor (D) and acceptor (A) heterojunction [1]. Fullerene $\left(\mathrm{C}_{60}\right)$ has been found to be an effective electron acceptor with conjugated polymers [6-8] and small molecules [9-11]. However, excitons near the D-A interfaces within the exciton diffusion length are only dissociated into free carriers [10]. In order to confine excitons near the D-A interface and thereby increase the charge separation in an organic solar cell with

\footnotetext{
*E-mail: chlee7@snu.ac.kr; Fax: +82-2-877-6668
}

a bilayer D-A heterojunction, a thin exciton blocking layer with a large bandgap and high ionization potential was introduced between $\mathrm{C}_{60}$ and $\mathrm{Al}$ electrodes [9, 10]. It was reported that 2,9-dimethyl-4,7-diphenyl-1,10phenanthroline (BCP) was an efficient exciton-blocking layer with a good electron-transporting property [9].

The charge carrier transport in amorphous organic thin films is limited by the disorder, resulting in low mobility and small short-circuit current $\left(I_{s c}\right)$ [12]. In addition, the space-charge effect in such materials reduces the open-circuit voltage $\left(V_{o c}\right)$ [12]. One way to improve the crystallinity of organic thin films and thereby improve the carrier mobility is to thermally anneal organic or polymeric photovoltaic cells [13-17]. Thermal annealing at high temperature (typically, $70 \sim 150{ }^{\circ} \mathrm{C}$ ) after device fabrication leads to enhanced device performance [1317]. Polymers and organic molecules were demonstrated to reorganize to form phase-separated crystalline clusters during thermal annealing, so the charge carrier mobility increased $[13,15,16]$. In addition, thermal annealing was claimed to eliminate microscopic shorts, thereby increasing the shunt resistance and resulting in a larger fill factor (FF) [17].

In this paper, we investigated the optimal conditions of the thermal annealing process for organic solar cells based on $\mathrm{CuPc} / \mathrm{C}_{60}$ heterojunctions and elucidated the effect of thermal annealing. We showed that a maxi- 
(a)

\begin{tabular}{|c|}
\hline $\mathrm{LiF} / \mathrm{Al}$ \\
\hline $\mathrm{BCP}$ \\
\hline $\mathrm{C}_{60}$ \\
\hline $\mathrm{CuPc}$ \\
\hline ITO \\
\hline
\end{tabular}

(b)

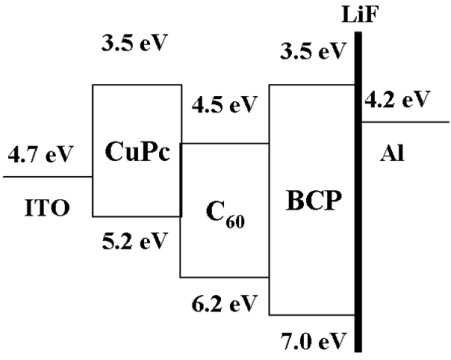

Fig. 1. (a) Schematic device structure and (b) energy band diagram of organic solar cells with a structure of $\mathrm{ITO} / \mathrm{CuPc} / \mathrm{C}_{60} / \mathrm{BCP} / \mathrm{LiF} / \mathrm{Al}$.

mum power conversion efficiency $\left(\eta_{p} \sim 1.3 \%\right)$ could be obtained at an annealing temperature of $100{ }^{\circ} \mathrm{C}$. We analyzed the effect of thermal annealing on the improved device performance by measuring the optical absorption spectra and the X-ray diffraction patterns of the $\mathrm{CuPc} / \mathrm{C}_{60}$ films.

\section{EXPERIMENT}

We fabricated organic solar cells with the structure of ITO/copper phthalocyanine $(\mathrm{CuPc}) / \mathrm{C}_{60} / \mathrm{BCP} / \mathrm{LiF} / \mathrm{Al}$. The BCP layer was inserted, as an exciton-blocking layer, between $\mathrm{C}_{60}$ and the $\mathrm{LiF} / \mathrm{Al}$ electrodes. Figure 1 shows the schematic device structure and the energy band diagram. The highest occupied molecular orbital (HOMO) and lowest unoccupied molecular orbital (LUMO) energies and work functions were taken from the literature $[9$, 10]. The indium-tin-oxide (ITO) substrates were cleaned successively using isopropyl alcohol, de-ionized water, acetone and methanol in an ultrasonic bath and dried an oven at $120^{\circ} \mathrm{C}$ for more than 30 minutes. After drying, the ITO substrates were exposed to ultraviolet ozone (UVO) treatment for 5 minutes prior to loading into the vacuum chamber. All materials were deposited by thermal evaporation under a base pressure of $<3 \times 10^{-6}$ Torr without breaking vacuum. In order to obtain an optimal thickness of the $\mathrm{CuPc}$ thickness, we varied its thickness in the range between $15 \mathrm{~nm}$ and $50 \mathrm{~nm}$ while keeping the $\mathrm{C}_{60}$ and the BCP thicknesses as $40 \mathrm{~nm}$ and $10 \mathrm{~nm}$, respectively. After the device fabrication in the vacuum chamber, the devices were transferred to a $\mathrm{N}_{2}$ glove box without exposing them to an ambient atmosphere; then, they were thermally annealed on a hot plate at various temperatures between room temperature and $180{ }^{\circ} \mathrm{C}$ for 30 minutes. The overlap area of the $\mathrm{Al}$ and ITO electrodes was about $1.96 \mathrm{~mm}^{2}$.

The current-voltage $(I-V)$ characteristics in the dark and under light illumination through the ITO side with a $300 \mathrm{~W}$ solar simulator were measured using a Keithley 237 source-measure unit. The power conversion efficiency was measured under the condition of an AM 1.5 solar illumination of $100 \mathrm{~mW} / \mathrm{cm}^{2}$ at room temperature.

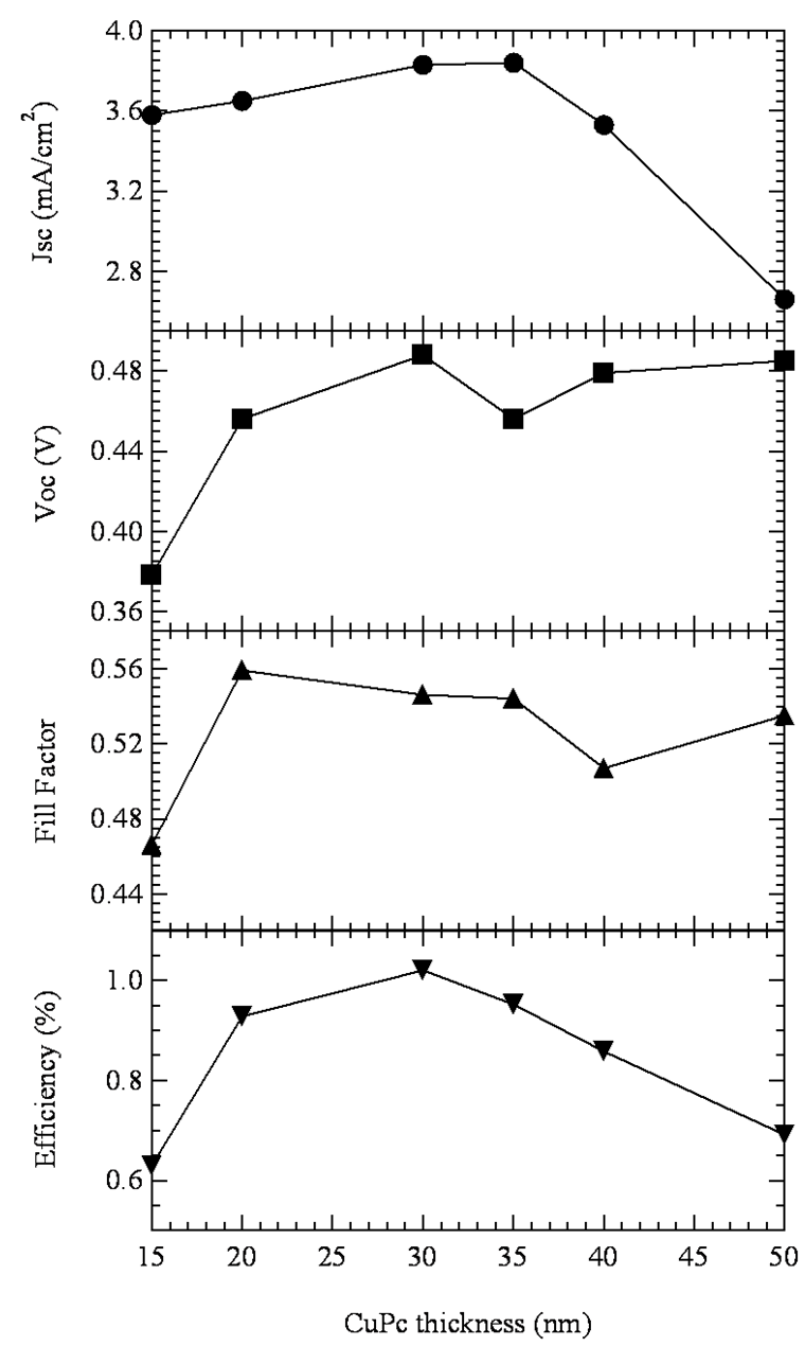

Fig. 2. Dependences of the $J_{s c}, V_{o c}$, fill factor and power conversion efficiency on the $\mathrm{CuPc}$ thickness under an AM1.5 solar illumination of $100 \mathrm{~mW} / \mathrm{cm}^{2}$.

\section{RESULT AND DISCUSSION}

Figure 2 shows the short-circuit current density $\left(J_{s c}\right)$, $V_{o c}, \mathrm{FF}$ and power conversion efficiency $\left(\eta_{p}\right)$ as functions of the $\mathrm{CuPc}$ thickness for thicknesses between $15 \mathrm{~nm}$ and $50 \mathrm{~nm}$. The photovoltaic properties were measured under an AM 1.5 solar illumination of $100 \mathrm{~mW} / \mathrm{cm}^{2}$ at room temperature. All devices show a rectifying behavior in the dark and photovoltaic effects under illumination. As the $\mathrm{CuPc}$ thickness was increased, the opencircuit voltage and the short-circuit current increased for thicknesses up to $30 \mathrm{~nm}$ and then decreases at larger thicknesses. Therefore, the power conversion efficiency shows a maximum value of about $1 \%$ at a $\mathrm{CuPc}$ thickness of $30 \mathrm{~nm}$. The photocurrent increases for thicker $\mathrm{CuPc}$ layers because the light absorption increases. However, charge carrier generation occurs only within an exciton diffusion length at the $\mathrm{CuPc} / \mathrm{C}_{60}$ interface [10]; therefore, further increases in the $\mathrm{CuPc}$ thickness do not 
Table 1. Device performance of organic solar cells with the structure of ITO/CuPc $(30 \mathrm{~nm}) / \mathrm{C}_{60}(40 \mathrm{~nm}) / \mathrm{BCP}(10$ $\mathrm{nm}) / \mathrm{LiF}(0.5 \mathrm{~nm}) / \mathrm{Al}(100 \mathrm{~nm})$ treated at different annealing temperatures for 30 minutes. The photovoltaic parameters are measured at room temperature under an AM 1.5 solar illumination intensity of $100 \mathrm{~mW} / \mathrm{cm}^{2}$.

\begin{tabular}{|c|c|c|c|c|}
\hline $\begin{array}{l}\text { Thermal Annealing } \\
\text { Temperature }\left({ }^{\circ} \mathrm{C}\right)\end{array}$ & $\begin{array}{c}J_{s c} \\
\left(\mathrm{~mA} / \mathrm{cm}^{2}\right)\end{array}$ & $\begin{array}{l}V_{o c} \\
(\mathrm{~V})\end{array}$ & $\mathrm{FF}$ & $\begin{array}{c}\text { Efficiency } \\
(\%)\end{array}$ \\
\hline No treatment & 3.51 & 0.45 & 0.57 & 0.90 \\
\hline 50 & 3.79 & 0.45 & 0.60 & 1.02 \\
\hline 70 & 4.16 & 0.47 & 0.61 & 1.18 \\
\hline 100 & 4.41 & 0.49 & 0.60 & 1.30 \\
\hline 130 & 4.03 & 0.51 & 0.57 & 1.17 \\
\hline 150 & 3.92 & 0.50 & 0.58 & 1.15 \\
\hline 180 & 3.64 & 0.41 & 0.37 & 0.55 \\
\hline
\end{tabular}

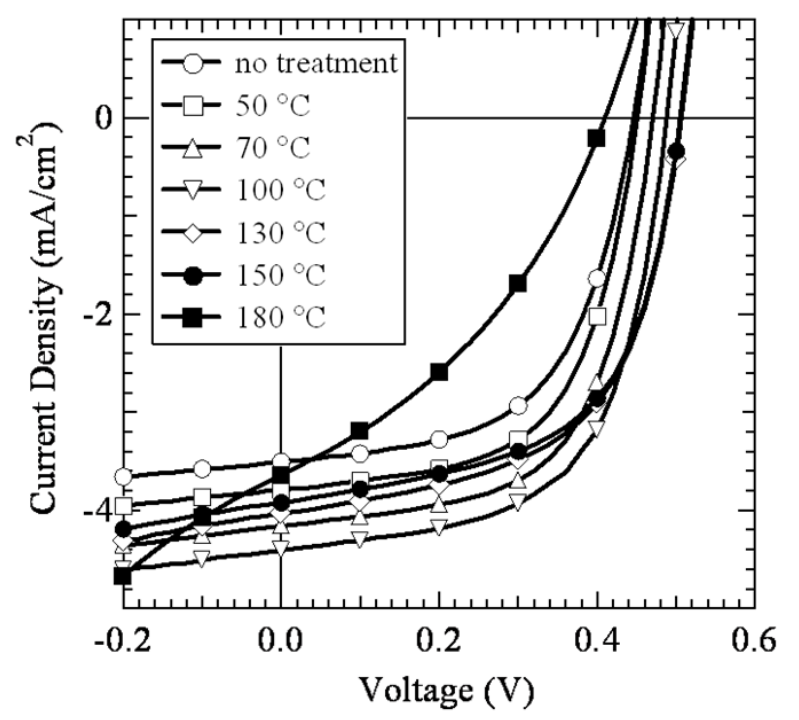

Fig. 3. Photocurrent-voltage characteristics for ITO/ $\mathrm{CuPc}(30 \mathrm{~nm}) / \mathrm{C}_{60}(40 \mathrm{~nm}) / \mathrm{BCP}(10 \mathrm{~nm}) / \operatorname{LiF}(0.5 \mathrm{~nm}) / \mathrm{Al}$ cells annealed at various temperatures for 30 minutes. The photocurrents were measured under an AM 1.5 solar illumination of $100 \mathrm{~mW} / \mathrm{cm}^{2}$ at room temperature.

increase the charge carrier generation, but increase the series resistance of the cell, resulting in a decrease in the short-circuit current. Therefore, one can think in a simple approximation that a maximum $\eta_{p}$ can be obtained at a $\mathrm{CuPc}$ thickness on the order of the exciton diffusion length [10]. The observed optimal CuPc thickness of $\sim 30$ $\mathrm{nm}$ is within the range of the exciton diffusion lengths of $10 \mathrm{~nm}$ [10] and $68 \mathrm{~nm}$ [18], previously reported in the $\mathrm{CuPc}$ layer. A more accurate simulation would require the effects of the carrier mobility and of the optical absorption, including optical interference effect to be considered [10].

The increase in $V_{o c}$ with increasing $\mathrm{CuPc}$ thickness may be attributed to the band bending of the $\mathrm{CuPc}$ layer

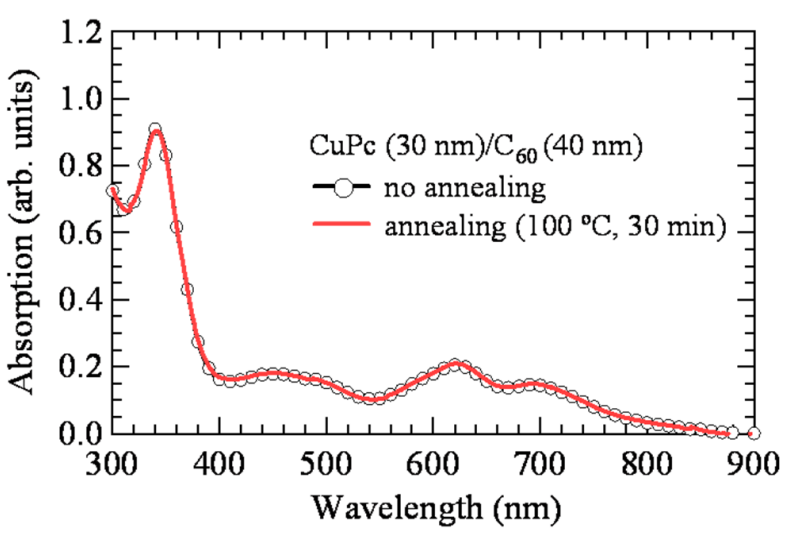

Fig. 4. Optical absorption spectra of the $\mathrm{CuPc} / \mathrm{C}_{60}$ film deposited on a quartz substrate before and after thermal annealing at $100{ }^{\circ} \mathrm{C}$ for 30 minutes.

deposited on an ITO substrate. The HOMO level was observed to shift with increasing $\mathrm{CuPc}$ thickness, deposited on an ITO substrate, up to several tens of nm and then to gradually become saturated to the bulk level [19]. Since the $V_{o c}$ of organic solar cells depends on the difference between the HOMO level of the donor and the LUMO level of the acceptor [5], the HOMO shift with the $\mathrm{CuPc}$ coverage will cause the $V_{o c}$ to change, as shown in Figure 2 .

Figure 3 shows the photocurrent-voltage characteristics, measured under an AM 1.5 solar illumination of 100 $\mathrm{mW} / \mathrm{cm}^{2}$ at room temperature, for the cells annealed at various temperatures for 30 minutes. All solar cells with an optimal $\mathrm{CuPc}$ thickness of $30 \mathrm{~nm}[\mathrm{ITO} / \mathrm{CuPc}(30$ $\left.\mathrm{nm}) / \mathrm{C}_{60}(40 \mathrm{~nm}) / \mathrm{BCP}(10 \mathrm{~nm}) / \operatorname{LiF}(0.5 \mathrm{~nm}) / \mathrm{Al}\right]$ were fabricated in the same batch thermal evaporation without breaking the vacuum. The photovoltaic parameters of the solar cells are summarized in Table 1 . The annealing temperature can be seen to have a significant influence on the device performance. As the annealing temperature was increased, the efficiency and the $J_{s c}$ increased for temperatures up to $100{ }^{\circ} \mathrm{C}$ and the open circuit voltage increased for temperatures up to $130^{\circ} \mathrm{C}$. At higher temperatures, the device performance decreased rapidly. The best annealing temperature was about 100 ${ }^{\circ} \mathrm{C}$ and the efficiency at this condition reached a maximum value of $1.3 \%$.

In order to investigate the effect of the thermal annealing on the improved performance, we measured the optical absorption spectra and the X-ray diffraction (XRD) patterns of $\mathrm{CuPc}(30 \mathrm{~nm}) / \mathrm{C}_{60}(40 \mathrm{~nm})$ heterojunction films before and after annealing at $100{ }^{\circ} \mathrm{C}$. Figure $4 \mathrm{com}-$ pares the optical absorption spectra of the $\mathrm{CuPc} / \mathrm{C}_{60}$ film deposited on a quartz substrate. Clearly, there is no change in the absorption spectra of the $\mathrm{CuPc} / \mathrm{C}_{60}$ film with and without thermal annealing at $100{ }^{\circ} \mathrm{C}$. Figure 5 exhibits the $\mathrm{XRD}$ patterns for $\mathrm{CuPc} / \mathrm{C}_{60}$ films deposited on glass substrates with and without thermal annealing at $100{ }^{\circ} \mathrm{C}$. There is only one diffraction peak around 


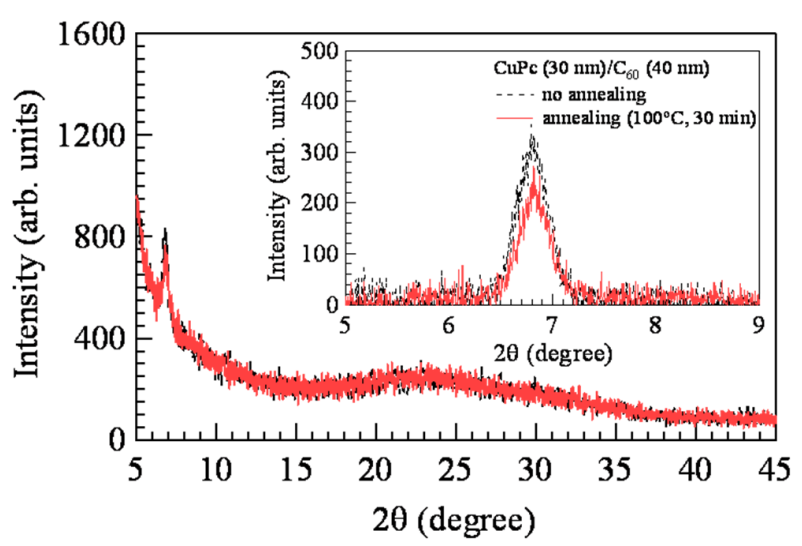

Fig. 5. XRD patterns for the $\mathrm{CuPc} / \mathrm{C}_{60}$ film deposited on a glass substrate before and after thermal annealing at $100{ }^{\circ} \mathrm{C}$ for 30 minutes. The inset compares the peak $(2 \theta=$ $6.9^{\circ}$ ) region where the background signal of the bare glass is subtracted from the XRD patterns of the $\mathrm{CuPc} / \mathrm{C}_{60}$ film.

$2 \theta=6.9^{\circ}$ and the inset of Figure 5 compares the peak region where the background signal of the bare glass is subtracted from the XRD patterns of the $\mathrm{CuPc} / \mathrm{C}_{60}$ film. The peak around $6.9^{\circ}$ corresponds to the diffraction from the (200) planes of CuPc separated by $12.6 \AA$ [20]. There is no XRD peak at $11^{\circ}$ corresponding to the $\mathrm{C}_{60}$ diffraction from the (111) planes, which was reported in the pentacene $/ \mathrm{C}_{60}$ heterojunction film [17]. Therefore, the XRD data in Figure 5 indicate that the $\mathrm{CuPc}$ film forms an ordered phase, but the $\mathrm{C}_{60}$ film forms a poorly ordered or amorphous phase. Although it is not so evident, we noticed that the full width at half maximum (FWHM) of the XRD peak at $6.9^{\circ}$ becomes slightly narrower for the $\mathrm{CuPc} / \mathrm{C}_{60}$ film annealed at $100{ }^{\circ} \mathrm{C}$, a FWHM of $\sim 0.32$ for the annealed film compared to a FWHM of $\sim 0.40$ for the non-annealed film. In addition, Bao et al. [20] reported that the field-effect mobility of the $\mathrm{CuPc}$ film increased with increasing substrate temperature during deposition $\left(T_{D}\right)$ up to about $125^{\circ} \mathrm{C}$ and then decreased at higher $T_{D}$, similar to the behavior of the $J_{s c}$ shown in Table 1. Based on these results, we suggest that the improved ordering of the $\mathrm{CuPc}$ film annealed at $100{ }^{\circ} \mathrm{C}$ may be responsible for the larger $J_{s c}$ (higher mobility) and the improved performance of the solar cell.

In addition, we can consider another possibility for the improved performance of the thermally-annealed solar cell. Since the maximum efficiency is obtained at an annealing temperature around $100{ }^{\circ} \mathrm{C}$, close to the glass transition temperature $\left(T_{g}\right)$ of $\mathrm{BCP}\left(\sim 80{ }^{\circ} \mathrm{C}[21]\right)$, the improved performance can also be attributed to better electrical contact at the interface between the $\mathrm{BCP}$ and the $\mathrm{LiF} / \mathrm{Al}$ electrodes. Thermal annealing at a temperature around or slightly higher than $\mathrm{Tg}$ of BCP causes molecular movement of BCP and interdiffusion of dissociated Li ions into the BCP layer. Thus, a Li-doped $\mathrm{BCP}$ layer (having higher electrical conductivity) can be formed at the $\mathrm{BCP} / \mathrm{LiF} / \mathrm{Al}$ interface and the decreased contact resistance improves the overall device performance. Since there is not much difference in optical absorption spectra and XRD patterns between the annealed and the non-annealed $\mathrm{CuPc} / \mathrm{C}_{60}$ films, we expect that the latter mechanism may be primarily responsible for the improved device performance under thermal annealing at $100{ }^{\circ} \mathrm{C}$.

\section{CONCLUSION}

We investigated the effect of thermal annealing treatment on the photovoltaic (PV) properties of organic solar cells based on $\mathrm{CuPc} / \mathrm{C}_{60}$ heterojunctions. We found that the device performance could be improved by using the proper $\mathrm{CuPc}$ thickness and thermal annealing process. A maximum power conversion efficiency of $\sim 1.3 \%$ under an AM 1.5 solar illumination of $100 \mathrm{~mW} / \mathrm{cm}^{2}$ was obtained with a 30-nm-thick $\mathrm{CuPc}$ layer and thermal annealing at $100{ }^{\circ} \mathrm{C}$ for 30 minutes. We analyzed the effect of thermal annealing on the improved device performance by measuring the optical absorption spectra and the $\mathrm{X}$-ray diffraction patterns of the $\mathrm{CuPc} / \mathrm{C}_{60}$ films. We suggest that the improved device performance for the cell annealed at $100{ }^{\circ} \mathrm{C}$ can be attributed to improve ordering of the $\mathrm{CuPc}$ film and to better electrical contact at the interface between the $\mathrm{BCP}$ and the $\mathrm{LiF} / \mathrm{Al}$.

\section{ACKNOWLEDGMENTS}

This work was supported by the Korea Science and Engineering Foundation (KOSEF) NRL Program grant (R0A-2008-000-20108-0) funded by the Korea government (MEST).

\section{REFERENCES}

[1] C. W. Tang, Appl. Phys. Lett. 48, 183 (1986).

[2] C. J. Brabec, N. S. Sariciftci and J. C. Hummelen, Adv. Funct. Mater. 11, 15 (2001).

[3] S. E. Shaheen, C. J. Brabec, N. S. Sariciftci, F. Padinger, T. Fromherz and J. C. Hummelen, Appl. Phys. Lett. 78, 841 (2001).

[4] K. M. Coakley and M. D. McGehee, Chem. Mater. 16, 4533 (2004).

[5] Organic Photovoltaics: Concepts and Realization, edited by C. J. Brabec, V. Dyakonov, J. Parisi and N. S. Sariciftci (Springer, Berlin, Germany, 2003), Vol. 60.

[6] H. Hoppe and N. S. Sariciftci, J. Mater. Res. 19, 1924 (2004)

[7] C. H. Lee, G. Yu, D. Moses, K. Pakbaz, C. Zhang, N. S. Sariciftci, A. J. Heeger and F. Wudl, Phys. Rev. B 48, 15425 (1993).

[8] I. S. Yoo, M. J. Lee, C. H. Lee, D.-W. Kim, I. S. Moon and D.-H. Hwang, Synth. Met. 153, 97 (2005). 
[9] P. Peumans, V. Bulovic and S. R. Forrest, Appl. Phys. Lett. 76, 2650 (2000).

[10] P. Peumans, A. Yakimov and S. R. Forrest, J. Appl. Phys. 93, 3693 (2003).

[11] Y.-J. Ahn, G.-W. Kang and C. H. Lee, Mol. Cryst. Liq. Cryst. 377, 301 (2002).

[12] M. C. Scharber, D. Muhlbacher, M. Koppe, P. Denk, C. Waldauf, A. J. Heeger and C. J. Brabec, Adv. Mater. 18, 789 (2006).

[13] F. Padinger, R. S. Rittberger and N. S. Sariciftci, Adv. Funct. Mater. 13, 85 (2003).

[14] H. J. Kim, W.-W. So and S.-J. Moon, J. Korean Phys. Soc. 48, 441 (2006).

[15] Y. H. Lee, I. H. Oh, K. W. Lee, S. M. Yoon and C. E.
Lee, J. Korean Phys. Soc. 51, 1457 (2007).

[16] P. Peumans, S. Uchida and S. R. Forest, Nature 425 , 158 (2003).

[17] A. C. Mayer, M. T. Lloyd, D. J. Herman, T. G. Kasen and G. G. Malliaras, Appl. Phys. Lett. 85, 6272 (2004).

[18] T. Stubinger and W. Brutting, J. Appl. Phys. 90, 3632 (2001).

[19] M. Andreasson, M. Tengelin-Nilsson, T. G. Andersson, L. Ilver and J. Kanski, Org. Electron. 6, 175 (2005).

[20] Z. Bao, A. J. Lovinger and A. Dodabalapur, Appl. Phys. Lett. 69, 3066 (1996).

[21] J. X. Sun, X. L. Zhu, X. M. Yu, H. J. Peng, M. Wong and H. S. Kwok, J. Display Tech. 2, 138 (2006). 